\title{
Halogenated Organic Compounds in Archived Whale Oil: A Pre-Industrial
}

\section{Record}

\author{
Emma L. Teuten* and Christopher M. Reddy
}

Department of Marine Chemistry and Geochemistry, Woods Hole Oceanographic Institution, 360 Woods Hole Rd, Woods Hole, MA 02543, USA.

Email addresses: ELT emma.teuten@plymouth.ac.uk; CMR creddy@whoi.edu

*Corresponding author: email: emma.teuten@plymouth.ac.uk; fax (+44)1752 232970; telephone (+44) 1752 233022; Present address: School of Biological Sciences, University of Plymouth, Drake Circus, Plymouth, Devon PL4 8AA, UK.

\footnotetext{
Abstract To provide additional evidence that several halogenated organic compounds (HOCs) found in environmental samples are natural and not industrially produced, we analyzed an archived whale oil sample collected in 1921 from the last voyage of the whaling ship Charles W. Morgan. This sample, which predates large-scale industrial manufacture of HOCs, contained two methoxylated polybrominated diphenyl ethers (MeO-PBDEs), five halogenated methyl bipyrroles (MBPs), one halogenated dimethyl bipyrrole (DMBP), and one dimethoxylated polybrominated biphenyl (diMeO-PBB). This result indicates, at least in part, a natural source of the latter compounds.
} 
Capsule Nine halogenated organic compounds have been detected in archived whale oil from the 1920s.

Keywords archived whale oil, natural products, halogenated organic compounds, bioaccumulation 


\section{Introduction}

During the past 80 years, the chemical industry has synthesized numerous halogenated organic compounds (HOCs) such as chlorinated pesticides, polychlorinated biphenyls (PCBs), and brominated flame retardants (Simonich 1995; Hites 2004). These HOCs are ubiquitously distributed in the environment (Scheringer et al., 2004). However, evidence is mounting that some HOCs found in animal tissues, air, humans, and food are not industrial but rather natural products. For example, two methoxylated polybrominated diphenyl ethers (MeOPBDEs) isolated from a True's beaked whale were shown to be natural by virtue of their radiocarbon content (Teuten et al., 2005). A similar analysis of an isolated mixed halogenated 2,2'-dimethyl bipyrrole (DMBP- $\left.\mathrm{Br}_{6} \mathrm{Cl}_{2}\right)$ revealed that it too was natural (Reddy et al., 2004).

Constraining the sources and cycling of these and other HOCs of unknown origin is important because their occurrence in an assortment of biota, including humans, indicates a widespread distribution in the environment. If these compounds are truly natural, they have likely been present in the environment for a much longer time period than industrially-synthesized HOCs. Hence they could be useful for studying the evolutionary response of biota to HOCs. They also have very similar chemical and physical properties to industrial HOCs, so could be excellent subjects to study the long-term fate of such compounds. Of course, if some of these compounds actually derive from industrial activity, careful consideration would need to be given as to their source, mode of production, fate, impact, and whether their emissions can or need to be controlled. 
Other possibly natural HOCs include a dimethoxylated polybrominated biphenyl (diMeO-PBBs) (Marsh et al., 2005), polybrominated dibenzodioxins (Malmvärn et al., 2005), tetrabrominated carbazoles (Zhu \& Hites, 2005), polychlorinated biphenyl carboxylic acids (Repeta et al., 2004) and a family of halogenated 1,2'-methyl bipyrroles (MBPs) (Vetter et al., 1999, 2000; Teuten et al., 2006a). The heptachlorinated MBP (referred to as Q1) has been found in breast milk of Faroe islanders who eat a diet rich in whale blubber (Vetter et al., 2000). Human exposure to halogenated natural products is not confined the Faroese, and is likely widespread. For example, $\mathrm{DMBP}-\mathrm{Br}_{4} \mathrm{Cl}_{2}$ has been observed in a variety of fish and seafood available for commercial retail throughout Canada. (Tittlemier, 2004).

While the MeO-PBDEs are biosynthesized by marine sponges (Anjaneyulu et al., 1996; Utkina et al., 2002), key arguments for a natural source for most of these other apparently natural compounds are (i) no record of industrial activity and (ii) efforts to synthesize them have often been difficult with low yields. To provide more definitive data on whether these compounds are truly natural without conducting a labor intensive radiocarbon analysis that needs $>5$ $\mathrm{kg}$ of animal tissue, we analyzed an archived whale oil sample collected on the last voyage of the whaling ship the Charles W. Morgan, which ended in 1921 and predates large-scale industrial manufacture of HOCs that began in the late 1920’s (Lipnick \& Muir, 2000).

\section{Methods and Materials}


A sample of whale oil ( $3 \mathrm{~g}$ ) from the last voyage of the Charles W. Morgan was obtained from the archives of the New Bedford Whaling Museum, in New Bedford, Massachusetts. The whale oil was originally collected directly from copper cooling pots (the shipboard containers in which the rendered blubber oil was cooled) onboard the Charles W. Morgan, and subsequently stored in the museum archives in a sealed glass bottle. To compare the HOC content of the whale oil, we also analyzed lipids from the blubber of a fin whale (Balaenoptera physalus) that was fatally stranded in June 2004 in Connecticut. The HOCs were isolated by gel permeation chromatography and were identified using gas chromatography mass spectrometry (GC-MS; Teuten et al., 2006a). In most cases, compounds were identified by comparison of their retention times and mass spectra, using both electron impact $(70 \mathrm{eV})$ and chemical ionization sources, with those of authentic standards. No standard was available for the diMeO-TBB. Its presence was suspected from its retention time and mass spectra compared with published data. To provide additional support for the presence of this compound, the sample was analyzed by high resolution mass spectrometry (HRMS). Data were acquired at 3,000 resolution by direct exposure ionization on an Autospec-Q mass spectrometer (acceleration voltage 6 $\mathrm{kV}$; ionization energy $20 \mathrm{eV}$ ). Perfluorokerosene was used as an internal calibration standard. Selected ion monitoring was used to look for the molecular isotope cluster $\mathrm{C}_{14} \mathrm{H}_{10} \mathrm{Br}_{4} \mathrm{O}_{2}$. The measured masses in the molecular ion isotopic cluster matched both the calculated masses and the calculated relative peak intensities. This method was also used to confirm the presence of Q1 
$\left(\mathrm{C}_{9} \mathrm{H}_{3} \mathrm{~N}_{2} \mathrm{Cl}_{7}\right), \mathrm{MBP}-\mathrm{Br}_{6} \mathrm{Cl}\left(\mathrm{C}_{9} \mathrm{H}_{3} \mathrm{~N}_{2} \mathrm{Br}{ }_{6} \mathrm{Cl}\right)$ and the methoxylated tetrabrominated diphenyl ethers (MeO-BDE-47 and MeO-BDE-68, $\left.\mathrm{C}_{13} \mathrm{H}_{9} \mathrm{Br}_{4} \mathrm{O}_{2}\right)$

Quantification of HOCs in the fin whale has been described previously (Teuten et al., 2006a). Authentic standards were used to quantify 1,1-dichloro2,2-bis(4-chlorophenyl)ethene (DDE), 2,2',4,4',5,5'-hexachlorobiphenyl (CB-153) and 2-(2',4'-dibromophenoxy)-3,5-dibromoanisole (6-MeO-BDE-47). The bipyrroles were assumed to have a comparable GC-FID response factor to $\mathrm{DMBP}_{-} \mathrm{Cl}_{6}$ and concentrations were estimated accordingly (Teuten et al., 2006a). The concentration of HOCs in the Charles W. Morgan whale oil sample was estimated by GC-MS, under previously described conditions (Teuten et al., 2006a). Where authentic standards were not available, GC-MS calibration curves were prepared by injecting mixtures containing the compounds of interest, whose concentrations had been determined by GC-FID using the surrogate standards described above.

An additional HOC that has not been previously reported was observed in the Charles W. Morgan sample. This compound was also observed in a common dolphin (Delphinus delphis) found stranded in Westpoint, Massachusetts in 2004. To isolate this compound, the HOCs were extracted from $5 \mathrm{~kg}$ of lipids from the blubber of the latter common dolphin. The novel compound, and other HOCs, were charged onto a glass column containing $3 \mathrm{~g}$ silica gel and $3 \mathrm{~g}$ aluminum oxide and eluted with hexane (in the $35-90 \mathrm{~mL}$ fraction). The compound of interest was isolated using preparative capillary gas chromatography (Eglinton et al., 1996), with $>99 \%$, determined by GC-FID. The accurate molecular weight was determined by HRMS (using the instrument described 
above) at 10,000 resolution. The measured accurate mass of the parent ion was compared to masses calculated for species with the following isotopic restrictions: $\mathrm{H}(0-20), \mathrm{C}(6-15), \mathrm{N}(0-2), \mathrm{Cl}(0-4), \mathrm{Br}(0-7), \mathrm{O}(0-4)$. The closest match between the measured and calculated masses, also containing an appropriate number of halogens to explain the observed isotopic pattern was $\mathrm{C}_{9} \mathrm{H}_{4} \mathrm{~N}_{2} \mathrm{Br}_{6}$. The difference between the calculated and measured masses was $-1.6 \mathrm{ppm}$.

\section{Results and Discussion}

HOCs were isolated from whale oil from the last voyage of the Charles $W$. Morgan using gel permeation chromatography and identified using GC-MS. Compounds were identified by either comparison of their relative retention times and mass spectra to authentic standards or by HRMS. Many of the HOCs assumed to be natural were detected (Table 1). No industrial HOCs were detected in the archived whale oil. The original collection date of the oil (predating large scale HOC manufacture), and absence of any known industrially synthesized HOCs, suggests that the observed compounds are natural. The absence of industrial HOCs in the oil assured us that we had a well-preserved sample that predated industrial activity, and had not been exposed to industrial releases during the past 80 years. It should be noted, however, that $\mathrm{Zhu}$ and Hites (2005) observed brominated carbazoles in a dated sediment core, pre-dating 1920. These compounds were not detected in the archived whale oil, and their origin is yet to be determined.

For comparison, concentrations of these HOCs in the blubber of a recently deceased fin whale were also analyzed (Table 1). In many cases the 
estimated concentration of HOCs from the archived whale oil is within an order of magnitude of those from the fin whale. However, comparison of HOC burden in marine mammals is complicated by variation between animals of different age, sex and species (Borgå et al., 2004). It is also possible that the HOC content in the archived whale oil may have decreased during its 83 years of storage. Numerous industrial HOCs were also detected in the fin whale; three examples are reported in Table 1.

The elemental compositions and chemical structures of the natural compounds identified in the archived whale oil are similar to those of industrial HOCs known to bioaccumulate (Figure 1). Octanol-water partition coefficients $\left(\mathrm{K}_{\mathrm{ow}}\right)$, which indicate a tendency for a molecule to partition into fats and tissues, are listed for each of the natural HOCs in Table 1 and are similar to typical industrial HOCs.

In the present study, an additional hexabrominated compound was observed in the archived sample that has not been previously reported as a bioaccumulated pollutant in marine mammal tissue. To aid in its identification, an identical compound was isolated from the blubber of a recently fatally stranded common dolphin. The molecular formula was determined as $\mathrm{C}_{9} \mathrm{H}_{4} \mathrm{~N}_{2} \mathrm{Br}_{6}$, using HRMS. We believe the most plausible structure for this compound is a hexabrominated 1'-methyl-1,2'-bipyrrole $\left(\mathrm{MBP}-\mathrm{HBr}_{6}\right)$, since it has very similar physical and chemical properties to other compounds recently proposed to contain this carbon skeleton (Teuten et al., 2006a, 2006b). Detection of this compound in both the archived whale oil and modern samples suggests that this also has a natural source. 
It is notable that Saint-Louis and Pelletier (2005) observed a large number of previously unidentified halogenated compounds in Atlantic white-sided dolphin (Lagenorhynchus acutus) liver samples. These compounds were originally proposed to be halogenated naphthols, although further investigation indicates the MBP structure is more likely (Teuten et al., 2006b). We have previously observed several $\mathrm{MBP}-\mathrm{HBr}_{5} \mathrm{Cl}$ isomers and hypothesize that these compounds may result from the debromination of $\mathrm{MBP}-\mathrm{Br}_{6} \mathrm{Cl}$ (Teuten et al., 2006a). It is reasonable to assume that some of the lower brominated compounds observed by Saint-Louis and Pelletier (2005) are additional dehalogenated products that originate from $\mathrm{MBP}-\mathrm{Br}_{6} \mathrm{Cl}$ and $\mathrm{MBP}-\mathrm{Br}_{7}$. Accordingly, it is possible that MBP$\mathrm{HBr}_{5} \mathrm{Cl}$ and $\mathrm{MBP}-\mathrm{HBr}_{6}$ in the archived whale oil result from dehalogenation of the same compounds.

\section{Conclusions}

Much as geoscientists have used ice and sediment cores to study the historical records of other chemical species, we observed a pre-industrial HOC record in the Charles W. Morgan whale oil. These results should motivate science to consider the ecological role and bioactivity of these natural HOCs and how preexposure to these compounds prepared bacteria, plants, animals, and humans for industrial HOCs introduced during the past century.

Most industrial HOCs degrade slowly in the environment (Sinkkonen \& Paasivirta, 2000). Hence with adequate regulations regarding the manufacture and release of these, and other persistent bioaccumulative HOCs, we can expect in 
the future that natural HOCs, rather than industrial ones, will again be more abundant in animal and human tissue.

\section{Acknowledgements}

The archived Charles W. Morgan whale oil was provided by the New Bedford Whaling Museum (New Bedford, Massachusetts). Blubber from the fin whale and common dolphin was provided by Mystic Aquarium (Mystic, Connecticut) and the Cape Cod Stranding Network, respectively. We are grateful to Bob Nelson, Sean Sylva, Li Xu, Byron Pedler and Alexandra Hangsterfer for assistance in and around the laboratory, to Travis Poole for help collecting samples, and to Jim Kent, Bruce Tripp, John Farrington and Mike Carlowicz who provided insightful comments on earlier drafts of this manuscript. Standards of $\mathrm{DMBP}_{-} \mathrm{Cl}_{6}$ and Q1 were synthesized by Gordon Gribble, David Blank and Fu Liangfeng at Dartmouth College. This work was supported by the National Science Foundation (OCE-0221181 and OCE-0550486), the Woods Hole Oceanographic Institution (WHOI) Ocean Life Institute and the Postdoctoral Scholar Program at WHOI (with funding from The Camille and Henry Dreyfus Foundation, Inc. and The J. Seward Johnson Fund).

\section{References}

Anjaneyulu V., Nageswara Rao K., Radhika P., Muralikrishna M., Connolly J.D., 1996. A new tetrabromodiphenyl ether from the sponge Dysidea herbacea of the Indian Ocean. Indian J. Chem. 35B, 89-90. 
Borgå K., Fisk A.T., Hoekstra P.F., Muir D.C.G., 2004. Biological and chemical importance in the bioaccumulation and trophic transfer of persistent organochlorine contaminants in arctic marine food webs. Environ. Toxicol. Chem. 23, 2367-2385.

Eglinton T.I., Aluwihare L.I., Bauer J.E., Druffel E.R.M., McNichol A.P., 1996. Gas chromatographic isolation of individual compounds from complex matrices for radiocarbon dating. Anal. Chem. 68, 904-912.

Hackenburg R., Schütz A., Ballschmiter K., 2003. High-resolution gas chromatography data as basis for the estimation of $\mathrm{K}_{\mathrm{ow}}$ values using $\mathrm{PCB}$ congeners as secondary standards. Environ. Sci. Technol. 37, 2274-2279.

Hites R.A., 2004. Polybrominated diphenyl ethers in the environment and in people: A meta-analysis of concentrations. Environ. Sci. Technol. 38, 945956.

Lipnick R.L., Muir D.C.G., 2000. History of persistent, bioaccumulative and toxic chemicals. In: Lipnick R.L., Hermens J.L.M., Jones K.C., Muir D.G. (eds) ACS Symposium Series 773. Chemicals in the Environment: Fate, Impact and Remediation. American Chemical Society, Washington, DC, p $1-12$.

Malmvärn A., Zebühr Y., Jensen S., Kautsky L., Greyerz E., Nakano T., Asplund L., 2005. Identification of polybrominated dibenzo-p-dioxins in blue mussels (Mytilus edulis) from the Baltic Sea. Environ. Sci. Technol. $39,8235-8242$.

Marsh G., Athanasiadou M., Athanassiadis I., Bergman Å., Endo T., Haraguchi K., 2005. Identification, quantification, and synthesis of a novel 
dimethoxylated polybrominated biphenyl in marine mammals caught off the coast of Japan. Environ. Sci. Technol. 39, 8684-8690.

Pontolillo J., Eganhouse R.P., 2001. The search for reliable aqueous solubility $\left(\mathrm{S}_{\mathrm{w}}\right)$ and octanol-water partition coefficient $\left(\mathrm{K}_{\mathrm{ow}}\right)$ data for hydrophobic organic compounds: DDT and DDE as a case study. Water-Resources Investigations Report 01-4201 (U.S. Geological Survey), 1-51.

Reddy C.M., Xu L., O'Neil G.W., Nelson R.K., Eglinton T.I., Faulkner D.J., Norstrom R., Ross P.S., Tittlemier S.A., 2004. Radiocarbon evidence for a naturally produced, bioaccumulating halogenated organic compound. Environ. Sci. Technol. 38, 1992-1997.

Repeta D.J., Hartman, N.T., John, S., Jones, A.D., Goericke, R., 2004. Structure elucidation and characterization of polychlorinated biphenyl carboxylic acids as major constituents of chromophoric dissolved organic matter in seawater. Environ. Sci. Technol. 38, 5373-5378.

Saint-Louis R., Pelletier E., 2005. Unsuspected organic pollutants in marine mammals: Halogenated naphthols. Mar. Pollut. Bull. 50, 889-903.

Scheringer M., Salzmann M., Stroebe M., Wegmann F., Fenner K., Hungerbühler K., 2004. Long-range transport and global fractionation of POPs: insights from multimedia modeling studies. Environ. Pollut. 128, 177-188.

Simonich S.L., 1995. Global distribution of persistent organochlorine compounds. Science 269, 1851-1854.

Sinkkonen S., Paasivirta J., 2000. Degradation half-life times of PCDDs, PCDFs and PCBs for environmental fate modeling. Chemosphere 40, 943-949. 
Teuten E.L., Xu L., Reddy C.M., 2005. Two abundant bioaccumulated halogenated compounds are natural products. Science 307, 917-920.

Teuten E.L., Pedler B.E., Hangsterfer A.N., Reddy C.M., 2006a. Identification of highly brominated analogues of Q1 in marine mammals. Environ. Pollut. In press, doi:10.1016/j.envpol.2005.10.052.

Teuten, E. L., Saint-Louis, R., Pedler, B., Xu, L., Pelletier, E., Reddy, C. M., 2006b. Expanding the range of brominated Q1 analogues. Mar. Pollut. Bull., 52, 578-582.

Tittlemier S.A., 2004. Dietary exposure to a group of naturally produced organohalogens (halogenated dimethyl bipyrroles) via consumption of fish and seafood. J. Agr. Food Chem. 52, 2010-2015.

Utkina N.K., Denisenko V.A., Virovaya M.V., Scholokova O.V., Prokof'eva N.G., 2002. Two new minor polybrominated dibenzo- $p$-dioxins from the marine sponge Dysidea dendyi. J. Nat. Prod. 65, 1213-1215.

Vetter W., Alder L., Palavinskas R., 1999. Mass spectrometric characterization of Q1, a $\mathrm{C}_{9} \mathrm{H}_{3} \mathrm{Cl}_{7} \mathrm{~N}_{2}$ contaminant in environmental samples. Rapid Commun. Mass Spectrom. 13, 2118-2124.

Vetter W., Alder L., Kallenborn R., Schlabach M., 2000. Determination of Q1, an unknown organochlorine contaminant, in human milk, Antarctic air, and further environmental samples. Environ. Pollut. 110, 401-409.

Zhu L.Y., Hites R.A., 2005. Identification of brominated carbazoles in sediment cores from Lake Michigan. Environ. Sci. Technol. 39, 9446-945 
Fig. 1. Chemical structures of a selection of halogenated compounds known to bioaccumulate in animal tissue.

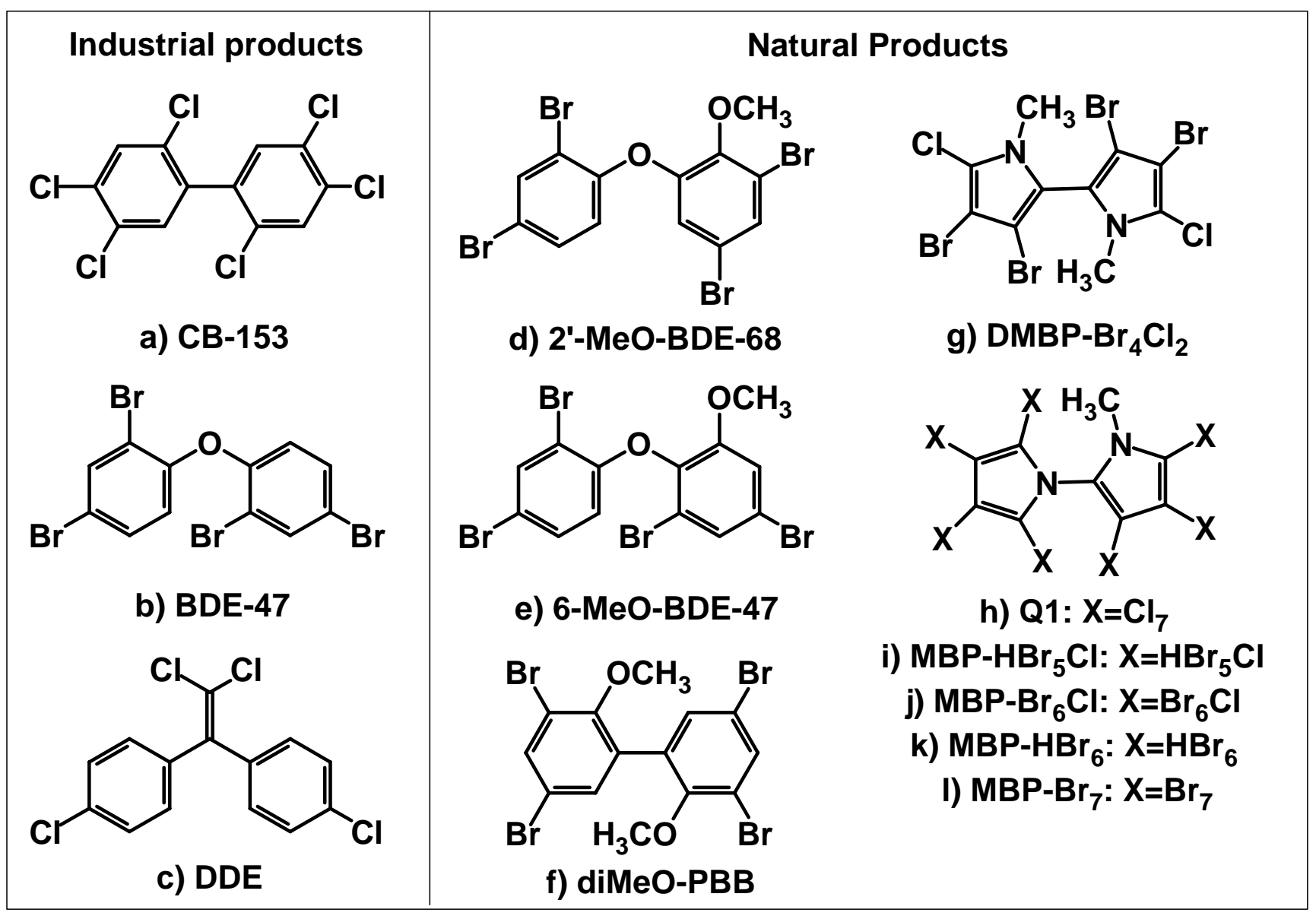


Table 1. HOCs in archived whale oil collected by the Charles W. Morgan (1921) and a fin whale (B. physalus; 2004).

\begin{tabular}{|c|c|c|c|c|c|c|}
\hline Compound & Acronym & $\begin{array}{l}\text { Elemental } \\
\text { composition }\end{array}$ & $\begin{array}{l}\text { Whale oil } \\
(\mu \mathrm{g} / \mathrm{g} \text { lipid })\end{array}$ & $\begin{array}{c}\text { Fin whale } \\
(\mu \mathrm{g} / \mathrm{g} \\
\text { lipid) }\end{array}$ & $\log \mathrm{K}_{\mathrm{ow}}{ }^{a}$ & $\begin{array}{l}\text { Relative } \\
\text { retention } \\
\text { time }^{b}\end{array}$ \\
\hline $\begin{array}{l}\text { 2-(2',4'-Dibromophenoxy)-3,5-dibromoanisole } \\
\text { (Fig. 1e) }\end{array}$ & 6-MeO-BDE-47 & $\mathrm{C}_{13} \mathrm{H}_{8} \mathrm{O}_{2} \mathrm{Br}_{4}$ & 0.09 & 0.2 & 6.9 & 1.174 \\
\hline $\begin{array}{l}\text { 2-(2',4'-Dibromophenoxy)-4,6-dibromoanisole } \\
\text { (Fig. 1d) }\end{array}$ & 2’-MeO-BDE-68 & $\mathrm{C}_{13} \mathrm{H}_{8} \mathrm{O}_{2} \mathrm{Br}_{4}$ & 0.03 & 0.2 & 6.9 & 1.156 \\
\hline $\begin{array}{l}\text { Chloro pentabromo 1'-methyl 1,2'-bipyrrole } \\
\text { Isomer A (Fig. 1i) }\end{array}$ & $\mathrm{MBP}-\mathrm{HBr}_{5} \mathrm{Cl}$ & $\mathrm{C}_{9} \mathrm{H}_{4} \mathrm{~N}_{2} \mathrm{Br}_{5} \mathrm{Cl}$ & 0.05 & 0.9 & 7.2 & 1.073 \\
\hline $\begin{array}{l}\text { Chloro pentabromo 1'-methyl 1,2'-bipyrrole } \\
\text { Isomer B (Fig. 1i) }\end{array}$ & $\mathrm{MBP}-\mathrm{HBr}_{5} \mathrm{Cl}$ & $\mathrm{C}_{9} \mathrm{H}_{4} \mathrm{~N}_{2} \mathrm{Br}_{5} \mathrm{Cl}$ & 0.02 & 0.04 & 7.2 & 1.063 \\
\hline Heptachloro 1'-methyl 1,2'-bipyrrole (Fig. 1h) & Q1 & $\mathrm{C}_{9} \mathrm{H}_{3} \mathrm{~N}_{2} \mathrm{Cl}_{7}$ & 0.02 & 0.2 & 6.6 & 0.922 \\
\hline Hexabromo 1'-methyl 1,2'-bipyrrole (Fig. 1k) & $\mathrm{MBP}-\mathrm{HBr}_{6}$ & $\mathrm{C}_{9} \mathrm{H}_{4} \mathrm{~N}_{2} \mathrm{Br}_{6}$ & 0.008 & 0.02 & 7.4 & 1.121 \\
\hline $\begin{array}{l}\text { Chloro hexabromo 1'-methyl 1,2'-bipyrrole } \\
\text { (Fig. 1j) }\end{array}$ & $\mathrm{MBP}-\mathrm{Br}_{6} \mathrm{Cl}$ & $\mathrm{C}_{9} \mathrm{H}_{3} \mathrm{~N}_{2} \mathrm{Br}_{6} \mathrm{Cl}$ & 0.006 & 0.2 & 8.1 & 1.227 \\
\hline $\begin{array}{l}\text { Dichloro tetrabromo 1,1'-dimethyl 2,2'- } \\
\text { bipyrrole (Fig. 1g) }\end{array}$ & $\mathrm{DMBP}-\mathrm{Br}_{4} \mathrm{Cl}_{2}$ & $\mathrm{C}_{10} \mathrm{H}_{6} \mathrm{~N}_{2} \mathrm{Br}_{4} \mathrm{Cl}_{2}$ & 0.002 & 0.005 & 6.5 & 1.158 \\
\hline $\begin{array}{l}\mathrm{C}_{14} \mathrm{H}_{10} \mathrm{Br}_{4} \mathrm{O}_{2} \text { (Dimethoxy tetrabromobiphenyl) } \\
{ }_{\text {(Fig. If) }}^{c}\end{array}$ & diMeO-PBB & $\mathrm{C}_{14} \mathrm{H}_{10} \mathrm{Br}_{4} \mathrm{O}_{2}$ & + & ++ & 7.5 & 1.156 \\
\hline $\begin{array}{l}\text { Chloro pentabromo 1'-methyl 1,2'-bipyrrole } \\
\text { Isomer C (Fig. 1i) }\end{array}$ & $\mathrm{MBP}-\mathrm{HBr}_{5} \mathrm{Cl}$ & $\mathrm{C}_{9} \mathrm{H}_{4} \mathrm{~N}_{2} \mathrm{Br}_{5} \mathrm{Cl}$ & $\begin{array}{c}\text { not } \\
\text { detected }\end{array}$ & 0.2 & 7.2 & 1.126 \\
\hline Heptabromo 1'-methyl 1,2'-bipyrrole (Fig. 1l) & $\mathrm{MBP}-\mathrm{Br}_{7}$ & $\mathrm{C}_{9} \mathrm{H}_{3} \mathrm{~N}_{2} \mathrm{Br}_{7}$ & $\begin{array}{c}\text { not } \\
\text { detected }\end{array}$ & 0.1 & 8.3 & 1.300 \\
\hline \multicolumn{7}{|l|}{ Industrial compounds ${ }^{e}$} \\
\hline $\begin{array}{l}\text { 1,1-Dichloro-2,2-bis(4-chlorophenyl)ethene } \\
\text { (Fig. 1c) }\end{array}$ & DDE & $\mathrm{C}_{14} \mathrm{H}_{8} \mathrm{Cl}_{4}$ & $\begin{array}{c}\text { not } \\
\text { detected }\end{array}$ & 3.2 & $7.0^{f}$ & 0.948 \\
\hline $2,2^{\prime}, 4,4^{\prime}, 5,5^{\prime}$-Hexachloro biphenyl (Fig. 1c) & CB-153 & $\mathrm{C}_{12} \mathrm{H}_{4} \mathrm{Cl}_{6}$ & not & 1.1 & $6.9^{g}$ & 1.000 \\
\hline
\end{tabular}




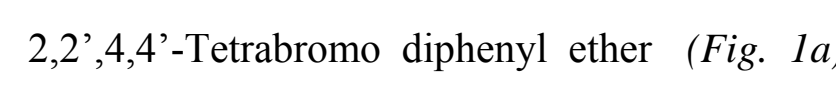

$\begin{array}{ccc} & \text { detected } \\ \text { BDE-47 } & \mathrm{C}_{12} \mathrm{H}_{6} \mathrm{OBr}_{4} & \text { not } \\ & \text { detected }\end{array}$

0.4

$5.9^{g}$

1.074

${ }^{a}$ Unless otherwise noted, $\log \mathrm{K}_{\mathrm{ow}}$ was calculated using Environmental Protection Agency EPI (Estimation Programs Interface)

Suite software (http://www.epa.gov/oppt/exposure/docs/episuitedl.htm). ${ }^{b}$ Retention time relative to CB-153, using a J \& W

Scientific DB-XLB column $(60 \mathrm{~m} \times 0.25 \mathrm{~mm}$ i.d., $0.25 \mu \mathrm{m}$ film thickness $)$ and temperature gradient program starting at $50{ }^{\circ} \mathrm{C}$ for 1 min then increasing at a rate of $30{ }^{\circ} \mathrm{C} / \mathrm{min}$ to $120{ }^{\circ} \mathrm{C}$ and then by $8{ }^{\circ} \mathrm{C} / \mathrm{min}$ to $320{ }^{\circ} \mathrm{C}$, which was held for 30 min.

${ }^{c}$ Tentative structural identification. ${ }^{d}$ diMeO-PBB was not quantified. ${ }^{e}$ Industrial compounds: CB-153 is one of the most abundant

PCB congeners, DDE is a metabolite of the pesticide DDT, and BDE-47 is a flame retardant, industrially synthesized since the

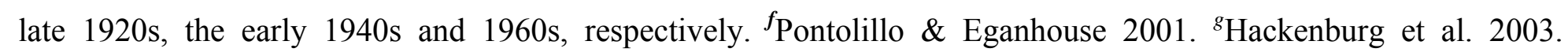


